\title{
Petro-archaeometric characterization of potteries from a kiln in Adrano, Sicily
}

\author{
Erica Aquilia ${ }^{1 \dagger}$, Germana Barone ${ }^{1 \dagger}$, Paolo Mazzoleni ${ }^{1 \dagger}$, Simona Raneri ${ }^{1{ }^{* \dagger}}$ and Gioconda Lamagna ${ }^{2 \dagger}$
}

\begin{abstract}
Background: This work is part of a wide scientific project finalized to characterize the Sicilian pottery productions from Greek to Roman Age. In this prospective, local reference groups have been analysed in order to create a database of the circulation and production centres in Sicily during this period. In this framework, a set of 28 waste pottery fragments (III-II century B.C.) from a pit found during excavations at the fortification of Adrano (Sicily) have been studied.

Characterization of the samples has been obtained by macroscopic, petrographic (OM), mineralogical (XRD) and chemical (XRF) analyses.

Results: Macroscopic analysis of the studied potteries has allowed to distinguish four groups on the basis of grain size, porosity and clay paste color. Petrographic and mineralogical analysis, carried out on a selection of representative samples have allowed us to obtain useful information on the production technology of the studied samples. Moreover, information about raw materials and provenance of clay sediments has been obtained by comparing chemical data of the analysed samples with locally outcropping clay sediments reference data. Finally, chemical results on Adrano potteries have been compared with kiln wastes from Siracusa and Gela.

Conclusions: The aim of the present work is to obtain fabric characterizations and technological information on a local reference group of ceramic specimens manufactured in Adrano (Sicily). Petrographic and mineralogical results allow us to esteem high firing temperature suggesting a good technological level of local production; in addition, chemical data suggest a local provenance of raw materials used in the production of the studied samples. The comparison with local production from Siracusa and Gela highlights several differences in the use of raw material and in the technological levels achieved in the different sites, over time. Therefore, this work provides a valuable contribution in defining the local scenario of ceramic production in South-Eastern Sicily during the Hellenistic Age and in producing local reference groups in the petro-archaeometric studies of archaeological potteries.
\end{abstract}

Keywords: Kiln wastes, Adrano (Sicily), Petro-archeometric analysis, Hellenistic pottery production

\section{Background}

The formation of reference groups represents an important procedure in archaeometric provenance studies of archaeological pottery. Materials from ancient kilns are thought especially suitable for reference groups, as they comprise a definite unit of production [1]. The discovery of a large number of kilns in Sicily and the presence of several clay formations suitable for ceramic manufacturing [2] suggests a prosperous production of potteries in

\footnotetext{
* Correspondence: sraneri@unict.it

${ }^{\dagger}$ Equal contributors

'Department of Biological, Geological and Environmental Sciences, University of Catania, C.so Italia 59, 95129 Catania, Italy

Full list of author information is available at the end of the article
}

ancient times. For these reasons, much research has been performed in recent years both on clays sediments [3-5] and kilns materials [6-10] with the aim of highlighting the features of Sicilian productions.

In the framework of the studies on circulation and production of ceramic artifacts in Sicily during Greek and Roman Age, several samples of kiln pottery fragments from a pit excavated at the fortification of Adrano (Sicily) $[11,12]$ have been studied. Historical sources established the foundation of the city by Dionysius I of Syracuse in V B.C.; however, some evidences suggest that a temple devoted to a local God named Adranos had previously been built. Due to its key position in the Aetnean area (Figure 1), at the end of the V century B.C., mercenaries 


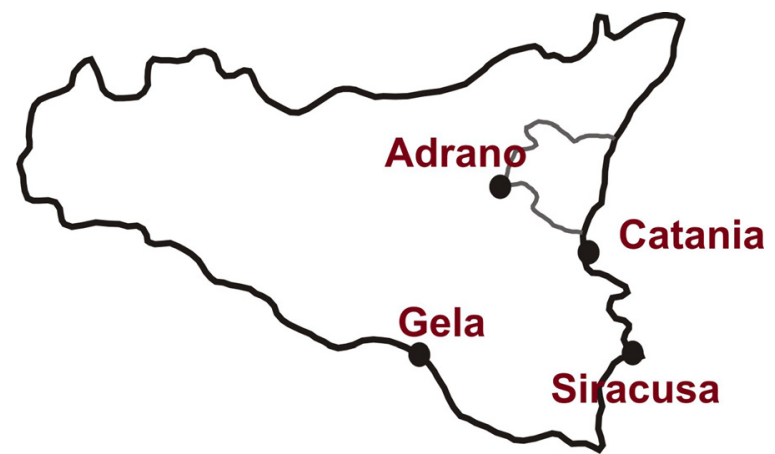

Figure 1 Geographic localization of the city of Adrano (Sicily).

from Siracusa established a settlement in the area of Adrano during a strategy of controlling the indigenous of Mendolito. The archeological evidence suggests a high relevance of the site from the Greek period related to the presence of a flourishing craft center (attested from IV to II century B. C.).

Topographically, the city of Adrano is located on the Western slopes of the Volcano Etna. From a geological point of view, the area is mainly characterized by volcanic products. In details, from the bottom to upwards, the stratigraphic series is formed by Numidian Flysch Fm. (alternation of brown clay and thick strata of yellowish quartz-arenite; Upper Oligocene-Burdigalian), followed by grey-blue and brown marly clays with foraminifera fauna (Terravecchia Fm. - Upper Tortonian). This sedimentary cover is overlapped by Aetnenan volcanic products; in particular, the area is characterized by a tholeiitic lava plateau (S. Maria di Licodia Fm.), followed by more recent alkaline products. The top of the series is represented by alluvial deposits and volcaniclastic sediments (Simeto Fm.) [13].

An excavation in the area of the ancient city reveals the presence of a pit including numerous kiln wastes; among them, a set of 28 wastes of medium-coarse pottery (III-II century B.C.) labeled as AD\# has been selected for petro- archeometric analyses. The studied materials are mainly represented by black and reddish varnished dishes exhibiting many manufacturing defects (i.e., vitrified surface with bubbles; deformation of surface; permanent waves on the rims). As examples, pictures of representative specimens are reported in Figure 2. In consideration of the importance of the city among the Sicilian potteries workshops, the petro-archaometric study of these artifacts has an important role in understanding the local manufacturing process in terms both technology and raw materials.

\section{Results}

\section{Macroscopic analysis}

Preliminary macroscopic analysis have been carried out with the aim of distinguishing samples on the basis of grain size, porosity and clay paste color (specified by Munsell Index = M.I.;[14]). The observations allow us to distinguish samples in three different groups (Table 1). In detail, group I consists of twenty samples characterized by a medium-coarse grain and a compact clay paste; the color range from red (M.I.: 2.5YR 4/2; specimens AD1, AD4, AD5, AD6, AD11, AD16, AD18, AD19, AD20, AD28) to reddish brown (M.I.:2.5YR 5/4-6;specimens AD3, AD9, AD14, AD15, AD21, AD23, AD24, AD25, AD25, AD27). A second group includes six samples (specimens AD2, AD8, AD10, AD13, AD17, AD22), characterized by medium-coarse grain, compact clay paste and color ranging from reddish-brow (M.I.5YR 5/3) to yellowish red (M.I. 5YR 5/6). Finally, specimens AD7, AD12 (i.e., group III) exhibit a medium-coarse grain, a porous clay paste and a dark-gray color (M.I. GLEY1 4/N).

\section{Petrographic and mineralogical analyses}

Thin section analyses have been made following Whitbread classification [15] on a selection of samples representative of the archeological typology and the previously identified macroscopic groups. Petrographically, all analysed samples exhibit common features such as dominant

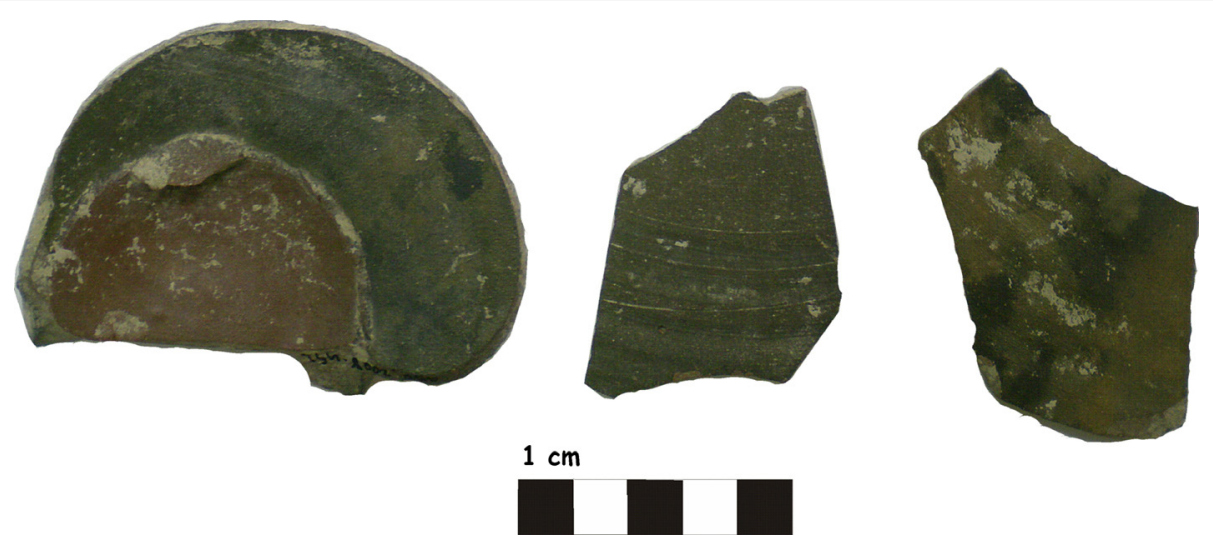

Figure 2 Pictures of some representative samples. AD2, AD12 and AD15 specimens are reported. 
Table 1 Macroscopic features of analysed samples

\begin{tabular}{llllll}
\hline Group & Color & M.I. & ID Samples & Grain size & Porosity \\
\hline I & dark reddish gray & 2.5 YR 4/2 & $\begin{array}{l}\text { AD1, AD4, AD5, AD6, AD11, AD16, } \\
\text { AD18, AD19, AD20, AD28 }\end{array}$ & Medium-coarse and compact & scarce \\
& reddish brown; yellowish red & 2.5 YR 5/4-6 & $\begin{array}{l}\text { AD3, AD9, AD14, AD15, AD21, AD23, } \\
\text { AD24, AD25, AD25, AD27 }\end{array}$ & \\
II & brown; dark brown & 5 YR 5/3-6 & AD2, AD8, AD10, AD13, AD17, AD22 & Medium-coarse and compact & scarce \\
III & dark gray & GLEY1 4/N & AD7, AD12 & Medium-coarse & medium-high
\end{tabular}

In Table 1 ID sample, clay paste color, grain size and porosity of analysed specimens for each group autoptically identified are summarized. M.I.: Munsell Index [14].

quartz and low groundmass birefringence; this unique petrographic fabric could be subdivided, however, into the following four sub-fabrics characterized by different groundmass and grain size features.

1. sub fabric $\mathrm{Q}^{\mathrm{VF}}$ (specimen $\mathrm{AD}$ 22; Figure 3a) - very fine pottery (VF), with micaceous groundmass and quartz inclusions. In detail, microstructure shows vugs, vesicles and planar voids with remains of carbonaceous material suggesting the use of straw as temper. Less abundant are vughy and slightly preferential oriented vesicles. The micaceous groundmass is homogeneous and it is characterized by low optical activity and brown-reddish color. The inclusions are mainly represented by very fine quartz and rare polycrystalline ones. Finally, abundant brownish-red amorphous phases are present.

2. sub fabric $\mathrm{Q}^{\mathrm{MF}}$ (specimen $\mathrm{AD}$ 10; Figure $3 \mathrm{~b}$ ) -medium-fine (MF) pottery with homogeneous groundmass and quartz inclusions. The microstructure voids are characterized by vugs and vesicles, the latter ones slightly preferential oriented. The groundmass rich in mica is globally homogeneous with rare microfossil moulds, medium-low birefringence and brown-reddish color. The grain size distribution of inclusions is unimodal with medium-fine quartz, feldspar, plagioclase and polycrystalline quartz; the fine grained inclusions are sub-angular in shape with sub-millimetric dimensions. Abundant, mainly brownish-red and black amorphous phases are also present.

3. sub fabric $\mathrm{Q}^{\mathrm{MC}}$ (specimens $\mathrm{AD}$ 8, $\mathrm{AD} 13, \mathrm{AD} 21$; Figure $3 \mathrm{c}$ ) - medium-coarse (MC) potteries with quartz and rocks fragments inclusions. The microstructure is characterized by abundant vugs and rare vesicles without preferential orientation. The groundmass with abundant microfossil moulds and scarce mica is quite heterogeneous
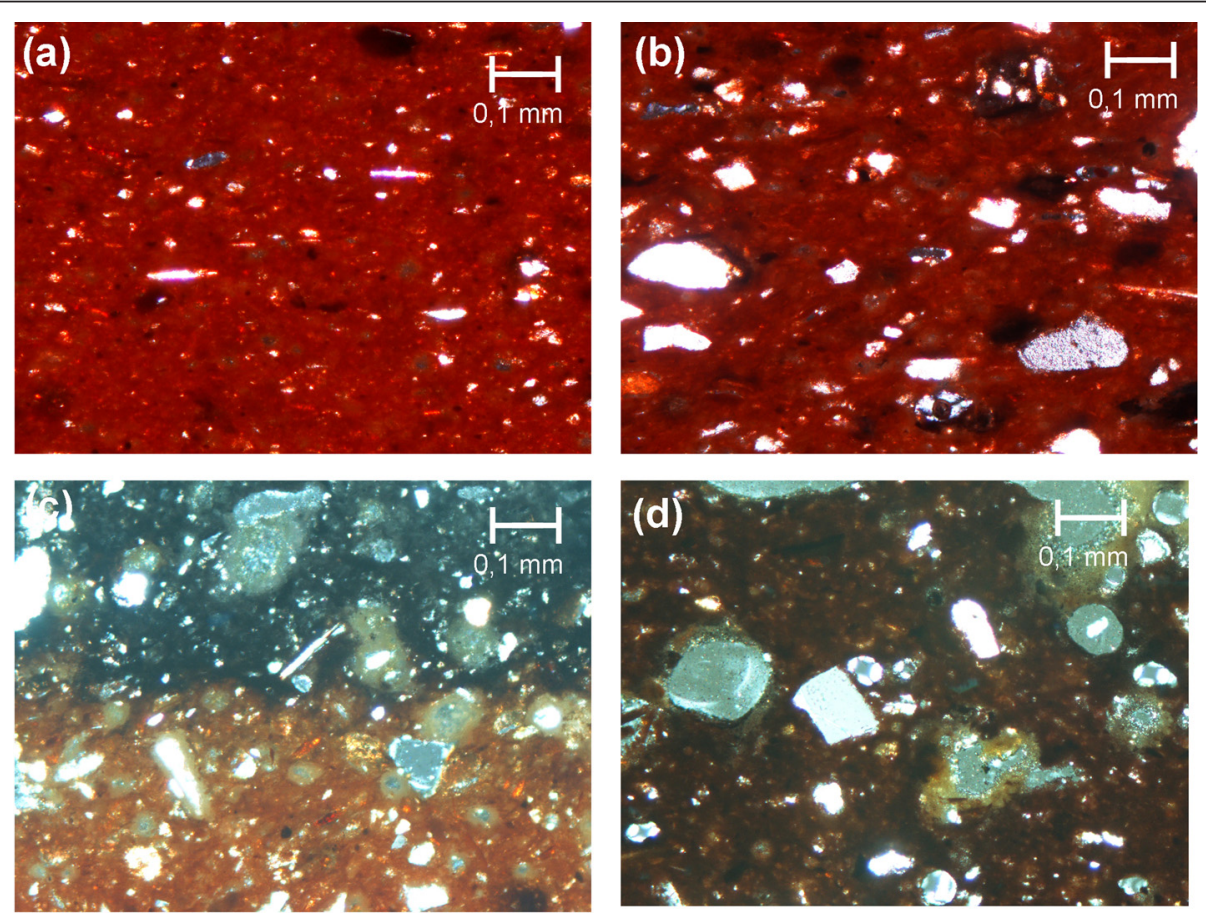

Figure 3 Microphotographs. Thin sections of the specimens belonging to the different sub-fabrics identified: (a) AD 22; (b) AD 10; (c) AD21; (d) AD 19. 
and exhibits a medium-low micromass optical activity and brown-reddish color. The inclusions are mainly fine grained and characterized by dominant medium-fine quartz sub angular in shape and rare feldspar, plagioclase, volcanic glass, metamorphic fragments and polycrystalline quartz sub-rounded in shape. Dark brown and black amorphous phase are present. Finally, samples are characterized by a millimetric dark brown slip.

4. sub fabric $\mathrm{Qp}^{\mathrm{MC}}$ (specimen $\mathrm{AD}$ 19; Figure 3d), medium-coarse $(\mathrm{MC})$ pottery with very heterogeneous and porous (p) groundmass and quartz inclusions. The microstructure voids are characterized by abundant rounded millimetric vugs. The groundmass is very heterogeneous with low birefringence and dark brown in color; it is also characterized by abundant microfossil moulds. The inclusions are mainly represented by medium-fine quartz, rare feldspar, plagioclase and polycrystalline quartz. Dark-brown amorphous phases are also present.

Overall, information on optical activity can be used for esteeming firing temperature [16]. In particular, low birefringence is, in many cases, indicative of the achievement of high firing temperature with reaction and modifications of the original mineralogical association of the raw materials. Hence, the petrographic observations performed on studied samples suggest high temperature of firing for all the sub-fabrics recognized.

As is well known, the firing process produces microstructural and microchemical changes in potteries due to reaction between mineral phases present in the clay [17-19]. In particular, during firing specific new minerals grow, depending on temperature and composition of clay (i.e., Ca-rich or Ca-poor clays). In details, referring to Ca-rich clays, the breakdown of calcite in calcium oxide and the reaction of the latter one with mineral phases present in the clay matrix determines the nucleation of diopside, gehlenite and anorthite, all indicative of high firing temperature $\left(850-900^{\circ} \mathrm{C}\right)$. Moreover, hematite also suggests high firing temperatures (from $550^{\circ} \mathrm{C}$ to $850^{\circ} \mathrm{C}$ ), in oxidizing firing atmosphere.

As aforementioned, mineralogical composition of potteries can be used to esteem firing temperature in archeological ceramics. Therefore, in order to confirm hypothesis on firing temperature suggested by petrographic analysis, $\mathrm{X}$-Ray diffraction analyses (XRD) have been carried out on a selection of 12 samples, which had been previously analysed in thin section. In the studied samples (AD2, AD4, AD8, AD10, AD12, AD13, AD18, AD19, AD21, AD22, $\mathrm{AD} 23, \mathrm{AD} 28)$, the semi-quantitative mineralogical data obtained from relative line intensities highlight the absence of calcite and clay minerals and the presence of diopside, anorthite and gehlenite (see Table 2). The
Table 2 Petrographic and mineralogical data

\begin{tabular}{llllllll}
\hline Sample & Bir & Qz & An & I/Ms & Geh & Hm & Di \\
\hline AD2 & $L$ & $x x x x$ & $x x x$ & tr & - & $x x$ & $x$ \\
AD4 & $L$ & $x x x x$ & $x x x$ & $x$ & - & $x x$ & - \\
AD8 & $L$ & $x x x x$ & $x x$ & $\operatorname{tr}$ & - & $x$ & - \\
AD10 & $L$ & $x x x x$ & $x x$ & $x$ & $\operatorname{tr}$ & tr & - \\
AD12 & $L$ & $x x x x$ & $x x x$ & $\operatorname{tr}$ & - & $x x$ & $x$ \\
AD13 & $L$ & $x x x x$ & $x x x$ & - & - & $x x$ & $x$ \\
AD18 & $L$ & $x x x x$ & $x x x$ & $\operatorname{tr}$ & - & $x$ & $x x$ \\
AD19 & $L$ & $x x x x$ & $x x x$ & $\operatorname{tr}$ & - & $x x$ & $x$ \\
AD21 & $L$ & $x x x x$ & $x x x$ & $\operatorname{tr}$ & - & $x x$ & $x$ \\
AD22 & $L$ & $x x x x$ & $x x x$ & - & $\operatorname{tr}$ & $x x$ & $x$ \\
AD23 & $L$ & $x x x x$ & $x x$ & tr & tr & $x$ & $x$ \\
AD28 & $L$ & $x x x$ & $x x x x$ & - & - & $x$ & $x x$ \\
\hline
\end{tabular}

Petrographic and mineralogical data of the studied samples. Bir. $=$ Birefringence: $\mathrm{L}=$ low or absent birefringence; $\mathrm{Qtz}=\mathrm{Quartz} ; \mathrm{An}=$ Anorthite; $\mathrm{I} / \mathrm{Ms}=$ illitemuscovite; Geh = gehlenite; $\mathrm{Hm}=$ Hematite; $\mathrm{Di}=$ diopside. The number of $(\mathrm{x})$ is related to the mineralogical phase abundance: $\mathrm{xxxx}=$ abundant; $\mathrm{xxx}=$ present; $x x=$ scarce; $x=$ rare; $\operatorname{tr}=$ trace.

results suggest high firing temperature for all analysed samples, according to petrographic data $\left(>850^{\circ} \mathrm{C}\right)$. Note worthy is that the presence of diopside in samples exhibiting volcanic tempers (sub fabric $\mathrm{Q}^{\mathrm{MC}}$ ) cannot be directly used as temperature fingerprint.

\section{Chemical analysis}

Chemical analyses have been performed on all the studied samples, with the aim of characterizing chemical composition and obtaining information about raw materials used in production processes. On the basis of the obtained data (see Table 3) and the variation diagrams $\mathrm{SiO}_{2} \mathrm{vs}$ $\mathrm{CaO}, \mathrm{TiO}_{2}, \mathrm{Fe}_{2} \mathrm{O}_{3}$ and $\mathrm{Cr}$ vs $\mathrm{Ni}$ (Figure 4) two chemical groups can be distinguished: the first group (i.e., group A; specimens $\mathrm{AD} 1, \mathrm{AD} 2, \mathrm{AD} 3, \mathrm{AD} 4, \mathrm{AD} 5, \mathrm{AD} 6, \mathrm{AD}$ 7, $\mathrm{AD}$ 8, $\mathrm{AD}$ 9, $\mathrm{AD}$ 11, $\mathrm{AD}$ 12, $\mathrm{AD} 13, \mathrm{AD} 14, \mathrm{AD} 15, \mathrm{AD} 17$, $\mathrm{AD} 18, \mathrm{AD} 19, \mathrm{AD} 20, \mathrm{AD} 21, \mathrm{AD} 22, \mathrm{AD} 27, \mathrm{AD} 28)$ characterized by high $\mathrm{CaO}$ (from 6.5 to 9.5 wt\%) high $\mathrm{TiO}_{2}$ and $\mathrm{Fe}_{2} \mathrm{O}_{3}$ and low $\mathrm{SiO}_{2}$ contents, and a second group (i.e., group $\mathrm{B}$; specimens AD 10, AD 16, AD 23, AD 24, AD 25, AD 26) characterized by lower $\mathrm{CaO}$ (5- 6\% approximately), $\mathrm{TiO}_{2}$ and $\mathrm{Fe}_{2} \mathrm{O}_{3}$ and higher $\mathrm{SiO}_{2}$ abundances. Referring to trace elements, samples belonging to group B show lower content in $\mathrm{Sr}, \mathrm{V}, \mathrm{Cr}, \mathrm{Ni}, \mathrm{Co}, \mathrm{Rb}, \mathrm{Y}, \mathrm{Zr}$, La and Ce (Figure 4) compared to group A.

\section{Discussion}

Petrographic, mineralogical and chemical data suggest an homogeneous production for the kiln wastes from Adrano.

In detail, all the analysed samples belong to a unique petrographic fabric characterized by dominant quartz and low groundmass birefringence. On the whole, petrographic and mineralogical results suggest a good technological level 
Table 3 Chemical composition of analysed samples

\begin{tabular}{|c|c|c|c|c|c|c|c|c|c|c|c|c|c|c|c|c|c|c|c|c|c|c|c|}
\hline & iroup & $\mathrm{O}_{2}$ & 2 & $\mathrm{O}_{3}$ & ${ }_{2} \mathrm{O}_{3}$ & 0 & 0 & 10 & $a_{2} O$ & ${ }_{2} \mathrm{O}$ & $\mathrm{O}_{5}$ & r & $V$ & $\mathrm{Cr}$ & 0 & $\mathrm{Ni}$ & $\mathrm{Zn}$ & $Y$ & $\mathrm{Zr}$ & b & $\mathrm{Ba}$ & $a$ & $\mathrm{Ce}$ \\
\hline 1 & A & 0.82 & 0.91 & 16.02 & 7.56 & 0.34 & 2.99 & 7.77 & 0.72 & 2.65 & & 226 & 0 & 9 & 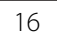 & 68 & 116 & 13 & 134 & 0 & 358 & 42 & 69 \\
\hline & 7 & & & & & & & & & & & & 08 & & 7 & 8 & & 4 & & 0 & & 4 & 55 \\
\hline D3 & A & & & & & & & & & & & & 147 & & 16 & 6 & & 2 & 147 & 4 & 1 & 8 & 98 \\
\hline & A & & & & & & & & & & & & 155 & & 17 & 3 & & 3 & & 15 & 9 & 36 & 05 \\
\hline 5 & A & & 88 & & & & 2.85 & 7.69 & & 2 & & 8 & 152 & 1 & 18 & 68 & 109 & 14 & 1 & 6 & 12 & 43 & 89 \\
\hline & 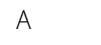 & & & & & & & & & & & & 123 & & 10 & 62 & & 7 & & & & 31 & 7) \\
\hline & A & & & & & & & & & & & & 152 & & 7 & 5 & & 10 & 9 & & 8 & 7 & 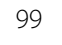 \\
\hline & $A$ & & 1 & 1660 & & & 3.3 & 662 & 0.8 & & & 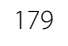 & 1 & & 11 & 62 & 95 & 7 & 107 & 0 & 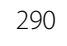 & 37 & 75 \\
\hline 9 & A & & & & & & & & & & & & 1 & & 14 & 7 & & 1 & 128 & 0 & & 48 & , \\
\hline 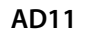 & 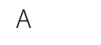 & 0.85 & 191 & 16.05 & & 0.34 & 3.09 & 7.78 & & 2.53 & & 7 & 155 & 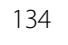 & 17 & 7 & 7 & 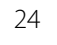 & 169 & 8 & 5 & 48 & \\
\hline & & & & & & & & & & & & & 1 & & 8 & 59 & & 3 & & & & 27 & 47 \\
\hline 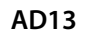 & & & 0 & 1 & & & 3 & & & & & 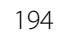 & 15 & 37 & 15 & 68 & 111 & $\varepsilon$ & 109 & 0 & 7 & 48 & 89 \\
\hline D14 & & & 01 & & & & & 1.71 & & & & 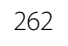 & 151 & 1 & 15 & 4 & 3 & 4 & 9 & 8 & 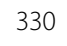 & 47 & (1) \\
\hline 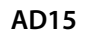 & & & & & & & & & & & & & 128 & & 12 & 59 & 7 & T & & & & 41 & 76 \\
\hline D17 & A & & & & & & & & & & & & 153 & & 16 & 68 & 113 & 13 & 144 & 3 & 7 & 41 & \\
\hline 18 & & & & & & & & & & & & 2 & 167 & 150 & 15 & 3 & 110 & 24 & & 9 & 42 & 40 & . \\
\hline 019 & 4 & 0.82 & (0) & 1623 & & & 3.00 & 755 & 066 & 252 & & 222 & 1 & 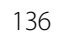 & 14 & 63 & 110 & 11 & 130 & 0 & y & 44 & 06 \\
\hline & A & & & & & & & & & & & & & & 12 & 63 & & 1 & & 3 & & 39 & \\
\hline 121 & A & & 0 & & 7.49 & & & 7.40 & & 4 & & 5 & 146 & 130 & 16 & 64 & 3 & 25 & 99 & 0 & 1 & 45 & 79 \\
\hline ברס & $\pi$ & & & & & & & & & & & & 141 & & 11 & 62 & & 2 & & 0 & 5 & 41 & 91 \\
\hline 27 & A & 9.20 & & 6.80 & 7. & 2 & 3.5 & 37 & 0. & 2.80 & & 5 & 141 & 122 & 13 & 3 & 107 & 21 & 47 & 0 & 11 & 4 & \\
\hline 820 & 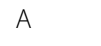 & 4.02 & & & & & 3.12 & 766 & & & & . & . & & 3 & 44 & 24 & 1 & & & 2 & 15 & 19 \\
\hline 0 & 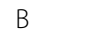 & & 0.86 & & 6.47 & & & & & & & 107 & 10 & 78 & 6 & 52 & $\mathrm{~J}$ & 2 & 00 & 0 & 3 & 24 & 40 \\
\hline AD16 & B & 4 & 0.76 & 1614 & 5.33 & 7ר? & 2.81 & 624 & 0.73 & 2.40 & 0.17 & 67 & 90 & 73 & 5 & 48 & 41 & 1 & 30 & 0 & 4 & 9 & 52 \\
\hline 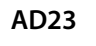 & D & 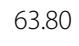 & 0.04 & & & & 3 & & & 2.58 & & & 77 & 10 & 5 & 50 & 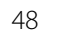 & 3 & 70 & 0 & 3 & 29 & t \\
\hline - & B & 1 & 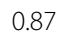 & 16.35 & 6.70 & 0.32 & - & 5.94 & - & 2.41 & 0 & 134 & 103 & 9 & 8 & 56 & 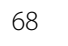 & 5 & 80 & 0 & 47 & 31 & 60 \\
\hline T2 & 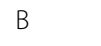 & 64.73 & 0.02 & S & 0.24 & 0.30 & 3.36 & & 0.78 & 2.J0 & 0.18 & o & 0 & 65 & 4 & 46 & . & 3 & & 0 & 4 & 5 & 21 \\
\hline D26 & B & 63.30 & 0.88 & 6.35 & 70 & .31 & 3.31 & 5.63 & 0.82 & 2.50 & 0.21 & 111 & 105 & 95 & 7 & 58 & 69 & 3 & 64 & 0 & 248 & 33 & 68 \\
\hline
\end{tabular}

Major elements are reported in wt\%. Minor elements are in ppm.

with high firing temperatures esteemed. In view of the homogeneity of studied samples, it is possible to assume that the slight differences among the identified sub-fabrics could be related to the heterogeneous features of the used clays or, alternatively, to different raw materials.

Effectively, chemical data suggests the use of two different raw materials, characterized by high $\mathrm{CaO}$ abundance (in group A specimens) and low $\mathrm{CaO}$ content (for group B samples), respectively.

With the aim of highlighting the features of local production in the framework of potteries manufacture in South-East Sicily during Hellenistic and Roman Age, data have been compared with pottery waste from kilns found in Gela [6] and Siracusa [7]. Moreover, in order to investigate the clay sediments used in local production processes, chemical data have been compared with locally outcropping clay formations [20].
Statistical treatment of chemical data (i.e., Aitchison log-ratio technique [21]; see Methods section) allow to obtain biplot in which the total variance of the chemical elements (major elements: $\mathrm{SiO}_{2}, \mathrm{TiO}_{2}, \mathrm{Al}_{2} \mathrm{O}_{3}, \mathrm{Fe}_{2} \mathrm{O}_{3}$, $\mathrm{MgO}, \mathrm{CaO}, \mathrm{K}_{2} \mathrm{O}$; minor elements: Sr, V, Cr, Co, Ni, Zn, $\mathrm{La}, \mathrm{Ce})$ and the studied samples are plotted in a plane defined by two principal component.

In the biplot of Figure 5, samples from Adrano have been compared with waste potteries from Siracusa and Gela. A detailed inspection of the diagram highlights the chemical features of the different productions suggesting the use of several raw materials in the manufactures which were analyzed. As aforementioned, with the aim to identify the different raw materials, chemical data on pottery productions from Adrano, Siracusa and Gela have been compared with Sicilian clay sediments suitable for the production of ceramic artifacts [20]. 


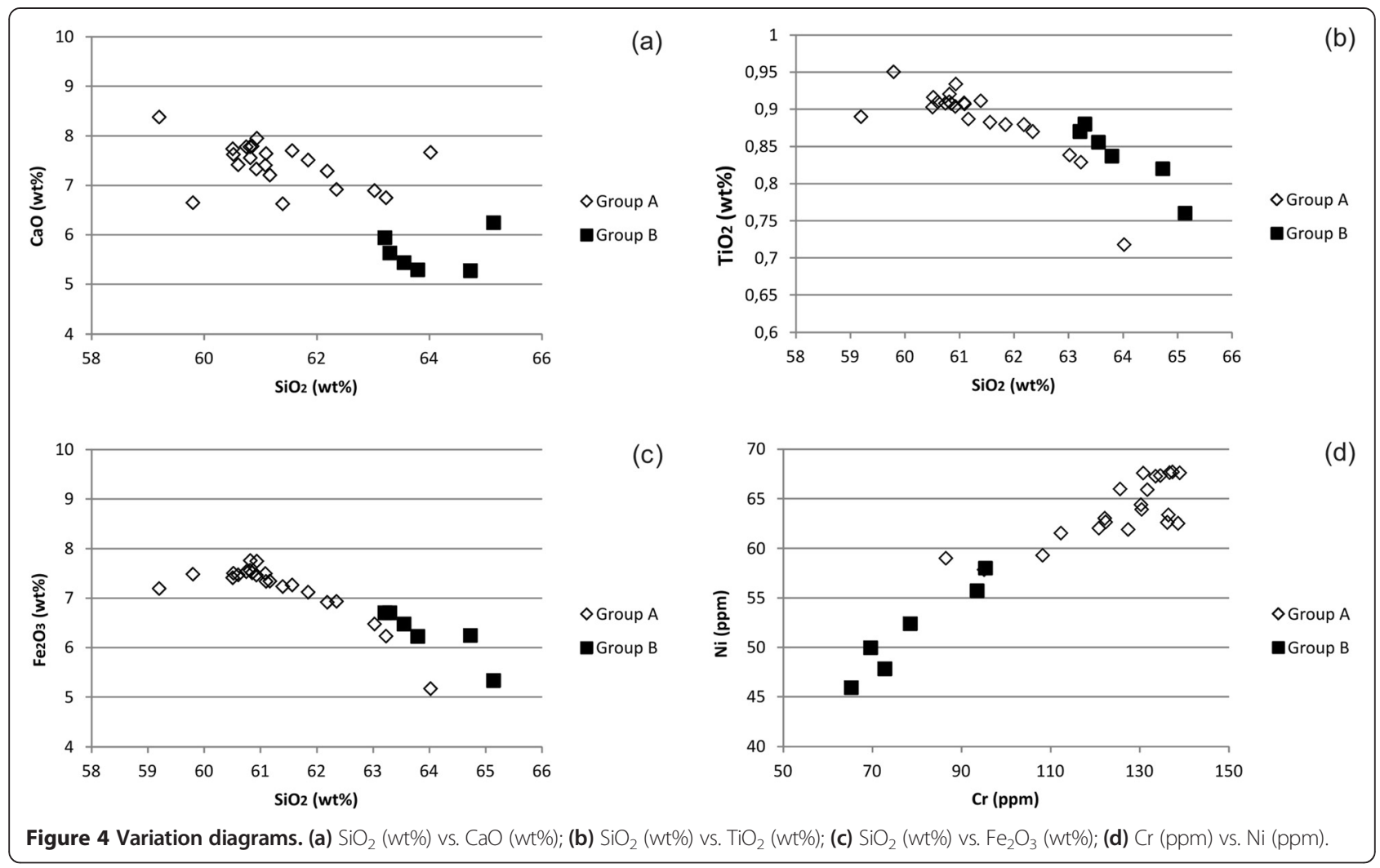

The obtained results (Figure 6) suggest the use of Terravecchia Fm. for the Ca-rich ceramics found in Adrano, while no correspondence has been found for Ca-poor potteries. On the contrary, for Gela and Siracusa production Plio-Pleistocene clays have been identified as raw materials.

\section{Conclusions}

The petro-archaeometric characterization of 28 kiln wastes from Adrano provides useful information on the production technology and the raw materials used in local ceramic production during IV - II century B. C.. In particular, petrographic and mineralogical results suggest a good technological level of local production considering the medium-high firing temperature esteemed. Furthermore, chemical data suggest the use of Tortonian sediments (Terravecchia Fm. Clays) for manufacturing some of analysed potteries, in spite of the well known use of Plio - Pleistocene clays in Eastern Sicily the ceramic production (i.e. Siracusa and Gela productions).

Therefore, this work provides a valuable contribution in defining the local scenario of ceramic production and in producing a local reference group in petroarchaeometric studies of archaeological pottery, also supplying an overview on South-Eastern Sicily production during the Hellenistic and Roman Age.

\section{Methods}

\section{Petrographic analysis}

Petrographic characterization was carried out on representative samples following a modified version of the classification scheme proposed by Whitbread [15].

\section{Mineralogical analysis}

X-ray diffraction (XRD) was performed on some samples, using a SIEMENS D 5000 with $\mathrm{Cu}-\mathrm{Ka}$ radiation and an $\mathrm{Ni}$ filter. Randomly oriented powders were scanned from $2^{\circ}$ to $45^{\circ} 2 \theta$, with a $0.02^{\circ} 2 \theta$ step size and a counting time of $2 \mathrm{~s}$ per step. The tube current and the voltage were $30 \mathrm{~mA}$ and $40 \mathrm{kV}$, respectively.

\section{Chemical analysis}

Chemical analyses for major oxides and trace elements were performed by X-ray fluorescence spectrometry (using a Philips PW 2404/00) on powder-pressed pellets of ceramic. Quantitative analysis was carried out using a calibration line based on 45 international rock standards. The limits of detection (LOD) were as follows: $\mathrm{SiO}_{2}=$ $1 \mathrm{wt} \%, \mathrm{TiO}_{2}=0.01 \mathrm{wt} \%, \mathrm{Al}_{2} \mathrm{O}_{3}=0.1 \mathrm{wt} \%, \mathrm{Fe}_{2} \mathrm{O}_{3}=0.05$ wt $\%, \mathrm{MnO}=0.01 \mathrm{wt} \%, \mathrm{MgO}=0.02 \mathrm{wt} \%, \mathrm{CaO}=0.05$ wt\%, $\mathrm{Na}_{2} \mathrm{O}=0.01 \mathrm{wt} \%, \mathrm{~K}_{2} \mathrm{O}=0.05 \mathrm{wt} \%, \mathrm{P}_{2} \mathrm{O}_{5}=0.01 \mathrm{wt} \%, \mathrm{~V}=$ $10 \mathrm{ppm}, \mathrm{Cr}=5 \mathrm{ppm}, \mathrm{Ni}=5 \mathrm{ppm}, \mathrm{Zn}=15 \mathrm{ppm}, \mathrm{Rb}=$ $5 \mathrm{ppm}, \mathrm{Sr}=10 \mathrm{ppm}, \mathrm{Y}=3 \mathrm{pm}, \mathrm{Zr}=20 \mathrm{ppm}, \mathrm{Nb}=2 \mathrm{ppm}$, 


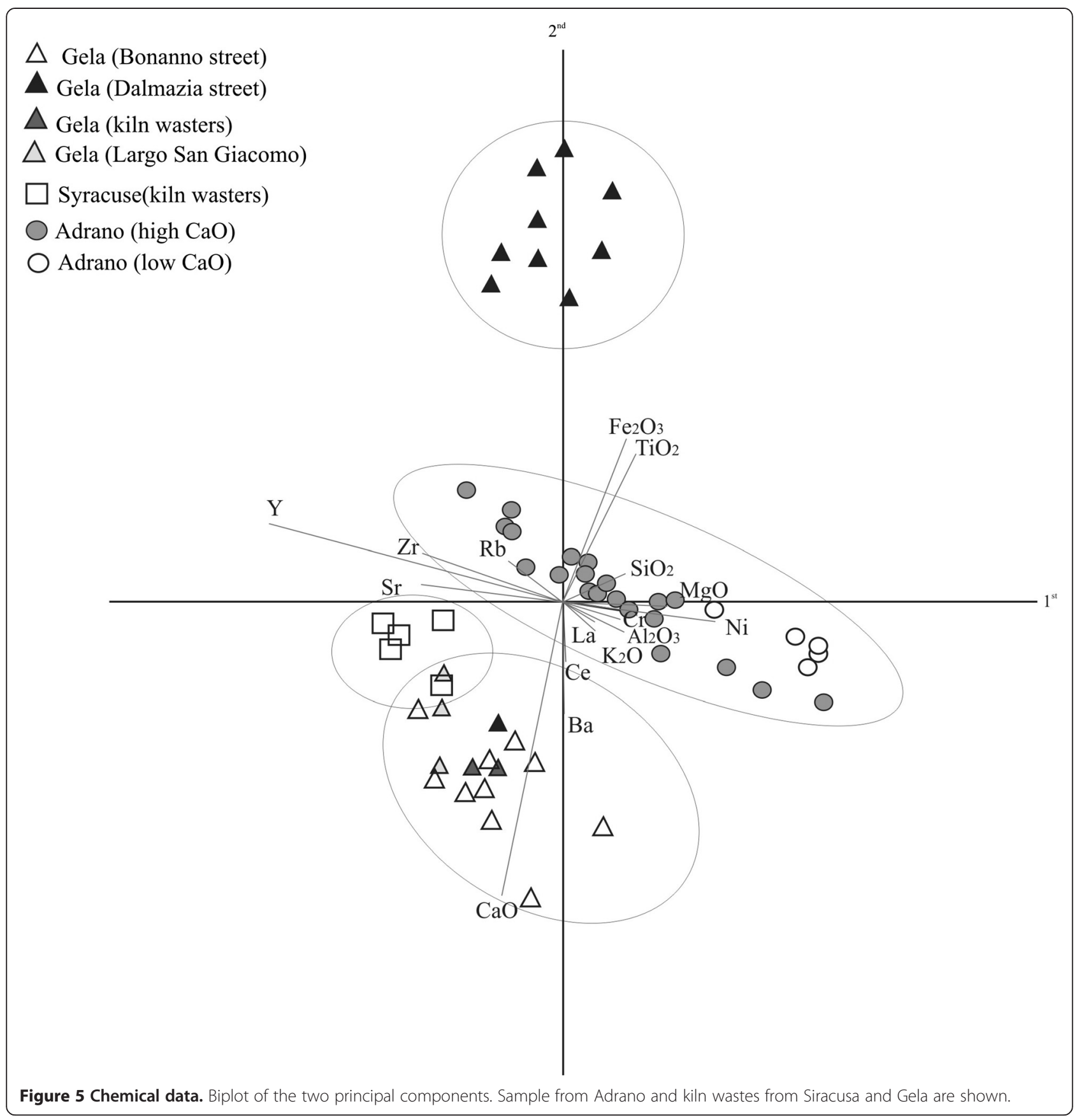

$\mathrm{Ba}=30 \mathrm{ppm}, \mathrm{La}=5 \mathrm{ppm}, \mathrm{Ce}=10 \mathrm{ppm}, \mathrm{Pb}=7 \mathrm{ppm}, \mathrm{Th}=$ $3 \mathrm{ppm}$. The precision was monitored by routinely running a well-investigated in-house standard (obsidian), while accuracy was evaluated using international standards compositionally similar to the samples analysed (SCO1 and SGR1). The average relative standard deviations (RSD) were less than 5\%. Finally, the accuracy was evaluated using an international standard (SGR1) that is compositionally similar to the analysed samples. The accuracy was good for major elements $(<3 \%)$, except for $\mathrm{MnO}$, and for trace elements $(5 \%)$.

Chemical data were treated with the statistical methodology mainly based on the log-ratio technique introduced by Aitchison [21] and employed in order to avoid the constant sum problem; the centred log-ratio transformation (clr) of data is applied as follows: $x \in S D \rightarrow y=$ $\ln (\mathrm{xD} / \mathrm{gD}(\mathrm{x})) \in \mathrm{RD}$ where $\mathrm{x}$ is the vector of the $\mathrm{D}$ elemental compositions, $y$ is the vector of the log-transformed 


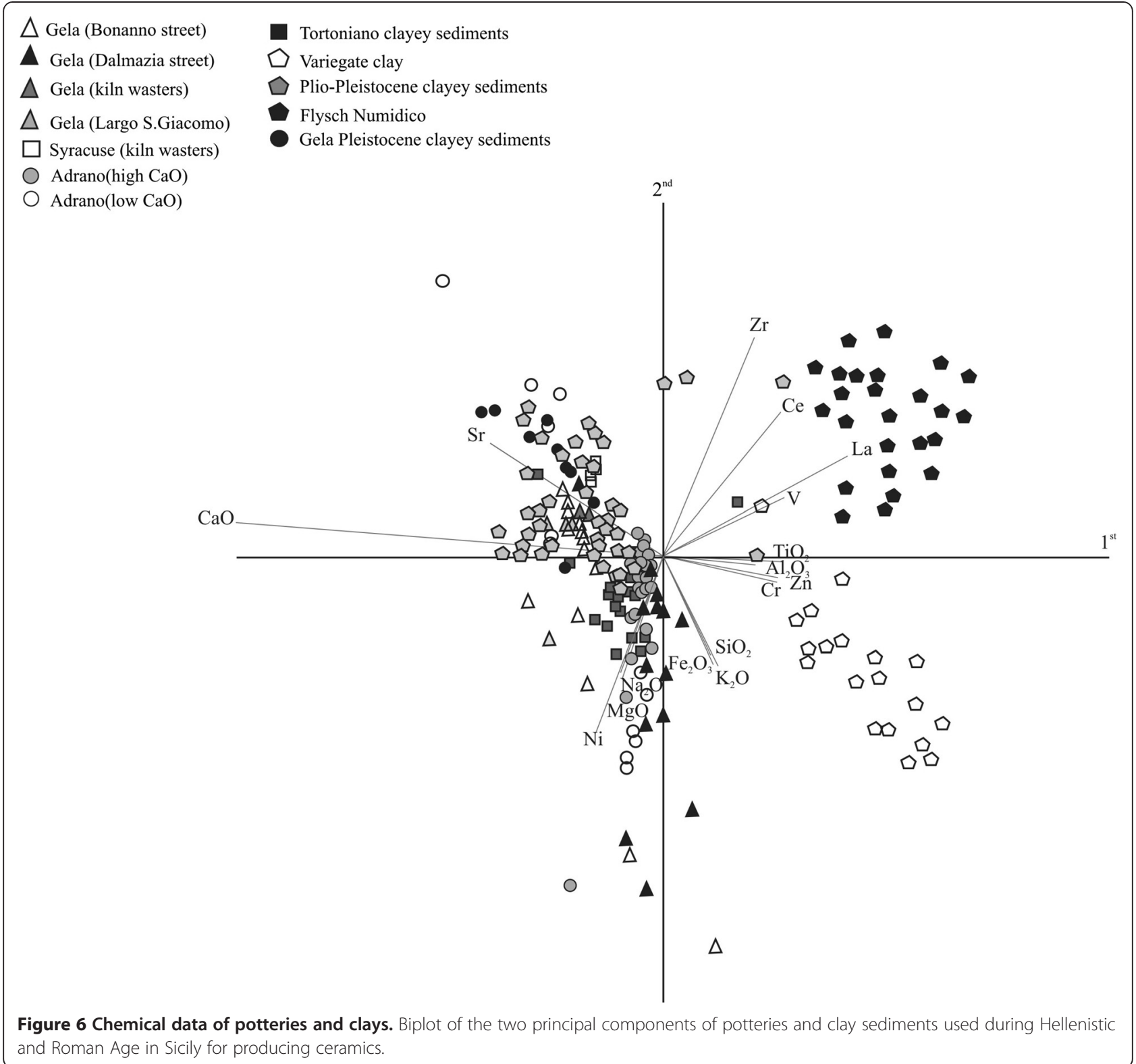

compositions, $\mathrm{xD}=(\mathrm{x} 1, \mathrm{x} 2, \ldots ., \mathrm{xD})$ and $\mathrm{gD}(\mathrm{x})$ $=(x 1 \bullet x 2 \bullet . \cdot x D) 1 / D$. This operation transforms the raw data from their constrained sample space, the simplex $\operatorname{Sd}(d=D-1)$, into the real space $R d$, in which parametric statistical methods can be applied to the transformed data. Subsequently, the clr-transformed data set was explored by biplots, a graphical representation of variables and cases projected on to principal component planes. Both the clr-transformation and the biplot calculations were obtained by using CoDaPack [22], a compositional software that implements the basic methods of analysis of compositional data based on log-ratios.

\section{Competing interests}

The authors declare that they have no competing interests.

\section{Authors' contributions}

The authors contributed equally to this work. All authors read and approved the final manuscript.

\section{Acknowledgements}

The authors are very grateful to Superintendence of Cultural and Environmental Heritages of Catania for kindly providing the studied materials.

\section{Author details}

'Department of Biological, Geological and Environmental Sciences, University of Catania, C.so Italia 59, 95129 Catania, Italy. ${ }^{2}$ Regional Archeological Museum Paolo Orsi, V.le Teocrito 66, 96100 Siracusa, Italy. 
Received: 12 June 2014 Accepted: 27 February 2015

Published online: 15 April 2015

\section{References}

1. Buxeda I, Garrigós J, Kilikoglou V, Day PM. Chemical and Mineralogical Alteration of Ceramics from A Late Bronze Age Kiln At Kommos, Crete: the Effect On the Formation of A Reference Group. Archeometry. 2003;43(3):349-71.

2. Montana G, CauOntiveros MÁ, Polito AM, Azzaro E. Characterisation of clayey raw materials for ceramic manufacture in ancient Sicily. Appl Clay Sci. 2011:53:476-88.

3. Montana G, Caruso A, Lavore AT, Polito AM, Sulli A. Inquadramento geologico e definizione composizionale delle "argille ceramiche" presenti nella Sicilia nord occidentale: ricadute di carattere archeometrico. Quaternario. 2006;19:279-98.

4. Barone G, Crupi V, Majolino D, Mazzoleni P, Teixeira J, Venuti V. Small angle neutron scattering as fingerprinting of ancient potteries from Sicily Southern Italy. J Appl Phys. 2009;106:054904.

5. Barone G, Mazzoleni P, Spagnolo G, Aquilia E. The Transport Amphorae of Gela: A Multidisciplinary Study on Provenance and Technological Aspects. J Archaeol Sci. 2012;39:11-22.

6. Aquilia E, Barone G, Mazzoleni P, Ingoglia C. Petrographic and chemical characterisation of fine ware from three Archaic and Hellenistic kilns in Gela, Sicily. J Cult Herit. 2012;13(4):442-7.

7. Barone G, Mazzoleni P, Aquilia E, Barbera G. The Hellenistic and Roman Syracuse (Sicily) fine pottery production explored by chemical and petrographic analysis. Archaeometry. 2014;56(1):70-87.

8. Barone G, Lo Giudice A, Mazzoleni P, Pezzino A, Barilaro D, Crupi V, et al. Chemical characterization and statistical multivariate analysis of ancient pottery from Messina, Catania, Lentini and Siracusa (Sicily). Archaeometry. 2005;47(4):745-62

9. Montana G, Polito AM, Iliopoulos I. Indigenous tableware production during the archaic period in western Sicily: new results from petrographic analysis. In: Quinn P, editor. Interpreting Silent Artefacts: Petrographic Approaches to Archaeological Ceramics. Oxford, U.K: Archaeopress; 2010. p. 47-63.

10. Montana G, Corretti A, Polito AM, Spatafora F. Ceramic production in the indigenous settlement of Entella (Western Sicily) during Archaic age. In: Proceedings of the 37th International Symposium on Archaeometry, Siena, Italy. 2011. p. 113-8.

11. Lamagna G. L'insediamento greco di Adranon tra Timoleonte e lerone II: i dati delle ultime ricerche. In: Congiu M, Miccichè C, Modeo S, editors. Timoleonte e la Sicilia della seconda metà del IV sec. a.C., Atti del VII Convegno di studi (Caltanissetta, 22-23 maggio 2010). Caltanissetta-Roma: Salvatore Sciascia; 2011. p. 57-63.

12. Lamagna G, Neri NF, Merendino A. La fortificazione di Adranon. Scavi e valorizzazione, Regione Siciliana. Palermo: Assessorato dei beni culturali e dell'identità siciliana, Dipartimento dei beni culturali e dell'identità siciliana; 2013.

13. Branca S, Coltelli M, Groppelli G, Lentini F. Geological map of Etna Volcano. Ital J Geosci. 2011;130(3):265-91.

14. Munsell AH, Color M. Munsell soil color charts. New Windsor, N.Y.; 2000.

15. Whitbread IK. Greek Transport Amphorae: A Petrological and Archaeological Study. In: The British School at Athens, Fitch Laboratory, Occasional Paper 4. 1995.

16. Barbera G, Barone G, Crupi V, Longo F, Maisano G, Majolino D, et al. Small angle neutron scattering study of ancient pottery from Syracuse (Sicily, Southern Italy). J Archaeol Sci. 2013:40(2):983-91.

17. Maggetti M. Phase analysis and its significance for technology and origin. In: Olin JS, Franklin AD, editors. Archeological Ceramics. Washington: Smithsonian Inst. Press; 1982. p. 121-33.

18. Riccardi MP, Messiga B, Duminuco P. An approach to the dynamics of clay firing. Appl Clay Sci. 1999;15:393-409.

19. Cultrone G, Rodriguez-Navarro C, Sebastian E, Cazalla O, De la Torre MJ. Carbonate and silicate phase reactions during ceramic firing. Eur J Mineral. 2001;13:621-34.

20. PRIN 2005-2007. Indagini petro-archeometriche per l'individuazione e la conoscenza delle produzioni ceramiche antiche in Italia meridionale ed in Sicilia.

21. Aitchison J. The statistics analysis of compositional data. London, UK: Chapman and Hall; 1986.

22. Thio-Henestrosa S, Martın-Fernandez JA. Dealing with compositional data: the freeware CoDaPack. Math Geol. 2005;37(7):773-93.

\section{Publish with ChemistryCentral and every scientist can read your work free of charge \\ "Open access provides opportunities to our colleagues in other parts of the globe, by allowing anyone to view the content free of charge." \\ W. Jeffery Hurst, The Hershey Company. \\ - available free of charge to the entire scientific community \\ - peer reviewed and published immediately upon acceptance \\ - cited in PubMed and archived on PubMed Central \\ - yours - you keep the copyright \\ Submit your manuscript here: \\ http://www.chemistrycentral.com/manuscript/ \\ () \\ Chemistry Central}

